\title{
VI. Analyses of farm-yard manure, and of coal-gas
}

\section{Thomas Richardson Esq.}

To cite this article: Thomas Richardson Esq. (1845) VI. Analyses of farm-yard manure, and of coal-gas, Philosophical Magazine Series 3, 27:177, 23-25, DOI: 10.1080/14786444508645218

To link to this article: http://dx.doi.org/10.1080/14786444508645218

册 Published online: 30 Apr 2009.

Submit your article to this journal $\pi$

Џll Article views: 2

Q View related articles $₫$ 
line and chloraniline has in reality the following composition:

$$
\mathrm{C}_{12}\left\{\begin{array}{l}
\mathrm{H}_{4} \\
\mathrm{Cl}_{3}
\end{array}\right\} \mathrm{N} \text {. }
$$

2nd. The chlorindatmit of Erdmann is nothing but trichloraniline.

3rd. The name chlorindoptene merely denotes an indefinite mix ture of chlorindoptenic acid and trichloraniline.

The formation of trichloraniline by the action of chlorine on indigo is not at all surprising. The transformation of indigo into nitropicric and chlorindoptenic acids, and into aniline, proves sufficiently that there are present in this body the conditions necessary for the production of all the members of the phenyle series. The action of potash and of chlorine on indigo is in this respect essentially the same. 'The only difference is, that in the first instance a pure product of oxidation is obtained, whilst in the second a number of the hydrogen equivalents of this pioduct is replaced by a corresponding number of the oxidlizing agent, viz. chlorine. In the one case aviline is formed, in the other trichloraniline. The latest investigations of Cahours*, in which he succeeded in obtaining salicylic acid by treating indigo with hydrate of potash, show that out of this latter substance hydrate of phenyle can likewise be produced, the compound free from chlorine, which corresponds to chlorindoptenic acid.

In an analogous manner Erdmann t obtained, by the action of bromine on indigo, bromisatine, dibromisatine and bromindoptene. This last substance, distilled with potash, is decomposed into bromindoptenic acid and bromindatmit. Erdmann did not analyse bromindatmit; but it is scarcely necessary to remark that this body is nothing but tribromaniline(Fritzsche's bromaniloid),

$$
\mathrm{C}_{12}\left\{\begin{array}{l}
\mathrm{H}_{4} \\
\mathrm{Br}_{3}
\end{array}\right\} \mathrm{N} \text {. }
$$

VI. Analyses of Farm-Yard Manure, and of Coal-Gas. By 'Thomas Richandson, Esq. $\ddagger$

THE accompanying analysis of farm-yard manure is part of an investigation in which $I$ am at present engaged, and the results show, rather unexpectedly, that this manure has a somewhat similar composition in different localities.

* Compt. Rend.

$\dagger$ Journ. für Prakt. Cheml, vol. xix. p. 358.

+ Communicated by the Chemical Society; having been read February 17,1845 . 
24 Mr. Richardson's Analyses of Farm-Yard Manure.

(See Boussingault's Economie Rurale.) The methods of analysis were those in general use. The manure was an average sample, and taken just previous to its being applied to the soil.

Farm-Yard Manure.

1. Fresh.

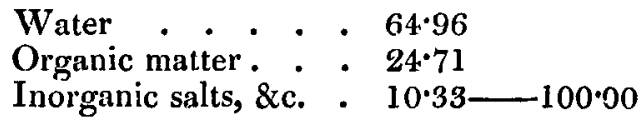

2. Dried at $212^{\circ}$.

Carbon . . . . $37 \cdot 40$

Hydrogen . . . . 5.27

Oxygen . . . . 25.52

Nitrogen . . . . $1 \cdot 76$

Ashes . . . . . 30.05-100.00

3. Inorganic Matter.

A. Portion Soluble in Water.

Potash . . . . 3.22

Soda . . . . . 273

Lime . . . . . 0.34

Magnesia . . . . 0.26

Sulphuric acid . . . $\quad 3.27$

Chlorine . . . . 315

Silica . . . . . 0.04-13.01

B. Portion partially Soluble in Muriatic Acid.

Silica . . . . . $27 \cdot 01$

Phosphate of lime . . $7 \cdot 11$

Phosphate of magnesia. $\quad 2 \cdot 26$

Phosphate of iron . . 4.68

Phosphate of manganese trace

Phosphate of alumina?. trace

Carbonate of lime . . $\quad 9.34$

Carbonate of magnesia. $\quad 1 \cdot 63$

Sand . . . . . . 30.99

Carbon . . . . . 83

Alkali and loss : . $3 \cdot 14 \frac{-86.99}{100 \cdot 00}$

The following analyses are of the coal-gas which is supplied to the town of Newcastle-on-'Tyne. It contained in 100 parts, - 
I.

\begin{tabular}{|c|c|c|c|}
\hline Olefiant gas . & . & $10 \cdot 19$ & $9 \cdot 25$ \\
\hline Carburetted hydr & gen. & $31 \cdot 35$ & $36 \cdot 05$ \\
\hline Hydrogen . & . & $28 \cdot 80$ & $30 \cdot 17$ \\
\hline Carbonic oxide & & $16 \cdot 28$ & $11 \cdot 42$ \\
\hline Azote. . & & $13 \cdot 35$ & $14 \cdot 01$ \\
\hline Carbonic acid . & & a trace & a trace \\
\hline Atmospheric air & & $0 \cdot 48$ & 0.50 \\
\hline Naphtha vapour & . & a trace & a tra \\
\hline Ammonia & & a trace & \\
\hline
\end{tabular}

VII. Contributions to Actino-Chemistry. By RoBert Hunt, Esq., Secretary to the Royal Cornwall Polytechnic Society, \&c.*

$\mathbf{M}^{\mathrm{A}}$

ANY of the changes produced upon photographic preparations, by the influence of the solar rays, are of a remarkable character, and few of them in the present state of our knowledge can be satisfactorily explained. In some instances it would appear that new properties are imparted to bodies by exposure to sunshine; in others, that radiation has the power of disturbing the known chemical forces, and apparently establishing a new order of affinities; whilst in all we are forced to recognise the operations of a principle, the nature of which is involved in the most perplexing uncertainty. In the hope of being enabled to follow ont some of these phenomena, under circumstances more favourable for investigation than those which offer themselves in the ordinary method of pursuing photographic experiments with the chemical compounds spread upon paper, where we have organic matter interfering with the results, I have been led to examine with attention the changes which take place under more simple conditions. It must be evident that a subject so extensive as this new branch of inquiry, embracing all material elements and their combinations, will not readily admit of satisfactory generalization; in this paper, indeed, I am scarcely able to do more than record a few facts, under particular heads, without any attempt at systematic arrangement.

'To prevent any misinterpretation of terms, or confusion of ideas, it will be necessary to make a few preliminary remarks. The researches of Sir John Herschel and others most distinctly prove that the Light, Heat and Chemical Power of the solar rays are three distinct classes of phæno-

* Communicated by the Chenical Society; having been read March 3, 1845. 